\title{
Plant growth regulation of Bt-cotton through Bacillus species
}

\author{
Pavan Kumar Pindi • Tasleem Sultana • \\ Praveen Kumar Vootla
}

Received: 18 May 2013/Accepted: 8 July 2013/Published online: 20 July 2013

(C) The Author(s) 2013. This article is published with open access at Springerlink.com

\begin{abstract}
Deccan plateau in India periodically experiences droughts due to irregular rain fall and the soil in many parts of the region is considered to be poor for farming. Plant growth promoting rhizobacteria are originally defined as root-colonizing bacteria, i.e., Bacillus that cause either plant growth promotion or biological control of plant diseases. The study aims at the isolation of novel Bacillus species and to assess the biotechnological potential of the novel species as a biofertilizer, with respect to their plant growth promoting properties as efficient phosphate-solubilizing bacteria. Seven different strains of Bacillus were isolated from cotton rhizosphere soil near boys' hostel of Palamuru University which belongs to Deccan plateau. Among seven isolated strains, Bacillus strain-7 has shown maximum support for good growth of eight cotton cultivars. This bacterial species is named Bacillus sp. PU-7 based on the phenotypic and phylogenetic analysis. Among eight cotton cultivars, Mahyco has shown high levels of IAA, proteins, chlorophyll, sugars and low level of proline. Efficacy of novel Bacillus sp. PU-7 with Mahyco cultivar has been checked experimentally at field level in four different cotton grown agricultural soils. The strains supported plant growth in almost all the cases, especially in the deep black soil, with a clear evidence of maximum plant growth by increased levels of phytohormone production and biochemical analysis, followed by shallow black soil. Hence, it is inferred that the novel isolate can be used as bioinoculant in the cotton fields.
\end{abstract}

P. K. Pindi $(\bowtie) \cdot$ T. Sultana · P. K. Vootla

Department of Microbiology, Palamuru University,

Mahabubnagar 509001, Andhra Pradesh, India

e-mail: pavankumarpindi@gmail.com
Keywords Bacillus sp. PU-7 · Cotton seed varieties . IAA $\cdot$ Proline $\cdot$ Proteins $\cdot$ Sugars

\section{Introduction}

A group of rhizosphere bacteria (rhizobacteria) that exert a beneficial effect on plant growth is referred to as plant growth promoting rhizobacteria (PGPR), belongs to several genera: e.g., Agrobacterium, Alcaligenes, Arthrobacter, Actinoplanes, Azotobacter, Bacillus, Pseudomonas sp., Rhizobium. Multiple species of Bacillus and Paenibacillus are known to promote plant growth. The principal mechanisms of growth promotion include production of growth stimulating phytohormones, solubilization and mobilization of phosphate, siderophore production, antibiosis, i.e., production of antibiotics, inhibition of plant ethylene synthesis, and induction of plant systemic resistance to pathogens (Richardson et al. 2009; Idris et al. 2007; Gutierrez-Manero et al. 2001; Whipps 2001).

Ability of Bacillus sp. to produce organic acid such as gluconic, citric and fumaric acids under P-limiting conditions may increase the solubility of poorly soluble phosphorus. Several soil bacteria and fungi notably species of Pseudomonas, Bacillus and Aspergillus, etc., secrete organic acids and lower the $\mathrm{pH}$ in their vicinity to bring about solubilization of bound phosphates in soil (Sundra Rao and Sinha 1963). The $\mathrm{N}_{2}$-fixing bacterium associated with nonlegumes includes species of Achromobacter, Alcaligenes, Arthrobacter, Acetobacter, Azomonas, Beijerinckia and Bacillus. Among PGPR species, IAA producing bacteria are belonging to Aeromonas (Halda-Alija 2003), Azotobacter (Ahmad et al. 2008) and Bacillus (Swain et al. 2007). 
Recently, Choudhary and Johri (2008) explicated the mechanisms and role of Bacillus species as inducers of systemic resistance in relation to plant-microbe interactions and demarcated the pathways involved in their regulation. Species of Bacillus are common inhabitants among the resident microflora of inner tissues of various species of plants, including cotton, grape, peas, spruce, and sweet corn, where they play an important role in plant protection and growth promotion (Berg et al. 2005; Shishido et al. 1999; Bell et al. 1995).

\section{Phytostimulation}

Root-colonizing species of Bacillus and Paenibacillus are well known for the enhancement of plant growth (Idris et al. 2007). Growth promoting effects of various PGPRs are due to bacterial production of plant growth regulators such as indole-3-acetic acid (IAA), gibberellins, and cytokinins (Bottini et al. 2004; Bloemberg and Lugtenberg 2001). $80 \%$ of rhizosphere colonizing bacteria has been reported positive for IAA production. Idris et al. (2004) showed production of substances with auxin (IAA)-like bioactivity from strains of Bacillus subtilis/B. amyloliquefaciens including strain FZB42. Gutierrez-Manero et al. (2001) has confirmed the production of gibberellins from B. pumilus and B. licheniformis. IAA plays an important key component in shaping plant root architecture such as root vascular tissue differentiation, regulation of lateral root initiation, polar root hair positioning, and root gravitropism (Aloni et al. 2006). Production of IAA from Gram-positive bacterium B. amyloliquefaciens FZB42 was first demonstrated by Idris et al. (2007) and its production was enhanced when the bacterium was fed with tryptophan. Application of phosphate solubilizers alone or in combination with nitrogen fixers has been found beneficial for cotton and wheat fields (Zaidi and Khan 2005; Kundu and Gaur 1980).

\section{Production of phytohormones by PGPR}

The production of phytohormones by PGPR is the most important mechanisms by which many rhizobacteria promote plant growth (Spaepen et al. 2007). Phytohormones are signal molecules acting as chemical messengers and play a fundamental role as growth and development regulators in the plants. Phytohormones are organic compounds that in extremely low concentrations influence biochemical, physiological and morphological processes in plants, and their synthesis is finely regulated (Fuentes-Ramírez and Caballero-Mellado 2006). Numerous fungal and bacterial species can produce phytohormones (Tsavkelova et al. 2006). The phytohormone producing ability is widely distributed among bacteria associated with soil and plants.
Studies have demonstrated that the PGPR can stimulate plant growth through the production of auxins (IAA) (Spaepen et al. 2008), gibberellins (Bottini et al. 2004) and cytokinins (Timmusk et al. 1999), or by regulating the high levels of endogenous ethylene in the plant (Glick et al. 1998).

Indole acetic acid (IAA) producing rhizobacteria

Many important plant-microbial interactions center on the production of auxins, IAA being the main plant auxin. It is responsible for the division, expansion and differentiation of plant cells and tissues and stimulates root elongation. IAA synthesis has been detected in many rhizobacteria as well as in pathogenic, symbiotic and free living bacterial species (Costacurta and Vanderleyden 1995; Tsavkelova et al. 2006).

Siderophore-producing rhizobacteria

Siderophores are produced by various types of bacteria in response to iron deficiency which occur in neutral to alkaline $\mathrm{pH}$ soils due to low iron solubility at elevated $\mathrm{pH}$ (Sharma and Johri 2003). Iron is essential for cellular growth and metabolism such that $\mathrm{Fe}$ acquisition through siderophore production plays an essential role in determining the competitive fitness of bacteria to colonize plant roots and to compete for iron with other microorganisms in the rhizosphere (Crowley and Gries 1994; Crowley 2006). Siderophore-producing organisms can prevent the proliferation of pathogenic microorganisms by sequestering $\mathrm{Fe}^{3+}$ in the area around the root (Siddiqui 2006).

\section{Materials and methods}

The experiments were carried out in the Department of Microbiology, Palamuru University, Mahabubnagar, Andhra Pradesh, India.

Sample collection

Cotton rhizosphere soil sample was collected near boys' hostel of Palamuru University and screened for Bacillus species by serial dilution of the sample and dilution of $10^{-4}$ was spread on Soya bean trypticase agar.

Preparation of standard inoculums of seven species of Bacillus

Inoculums of seven isolates of Bacillus sp. were prepared in selective medium. $150 \mathrm{ml}$ broth medium was inoculated in 500-ml conical flask and incubated at $28{ }^{\circ} \mathrm{C}$ under 
shaking at $100-150 \mathrm{rpm}$ for 3 days to give an optical density of 0.5 . Broth culture of Bacillus sp. was inoculated in to peat $\left(100 \mathrm{ml} \mathrm{kg}^{-1}\right.$ of peat) which was sterilized at $121{ }^{\circ} \mathrm{C}$ and $15 \mathrm{psi}$ pressure for $1 \mathrm{~h}$. Peat-based Bacillus inoculums were incubated at $28{ }^{\circ} \mathrm{C}$ by adding $10 \%$ sugar solution for 3-4 days to increase the population up to $10^{8} \mathrm{CFU} \mathrm{ml} \mathrm{m}^{-1}$. Bacillus inoculations having at $10^{8} \mathrm{MPN}$ bacterial cells per gram of peat were applied to cotton seed as seed coating for a period of 90 days in sterilized soil.

Preparation of sterilized soil

1:1 ratio of sand and red soil were mixed properly and sterilized in an autoclave at $121{ }^{\circ} \mathrm{C}, 15 \mathrm{lbs}$ pressure.

\section{Genomic DNA extraction}

The genomic DNA from the bacterial cells was obtained using a modification of the method described by Sambrook et al. (1989). The bacterial cells from pure culture were harvested by centrifugation $(12,000 \mathrm{rpm})$ for $2 \mathrm{~min}$, and the cell pellets were mixed with $600 \mu \mathrm{l}$ of lysis buffer [10 mM Tris-HCl, $1 \mathrm{mM}$ EDTA (pH 7.5), 0.5\% SDS, $100 \mathrm{~g} \mathrm{ml}^{-1}$ proteinase C] and incubated at $37{ }^{\circ} \mathrm{C}$ for $1 \mathrm{~h}$ after the addition of $100 \mu \mathrm{l} \mathrm{M} \mathrm{NaCl}$, and $80 \mu \mathrm{CTAB} /$ $\mathrm{NaCl}$ buffer. Samples were incubated at $65{ }^{\circ} \mathrm{C}$ for $10 \mathrm{~min}$ and samples were cooled to room temperature, followed by extraction of the aqueous phase with an equal volume of chloroform:isoamyl alcohol $(24: 11, \mathrm{v} / \mathrm{v})$ and then with an equal volume of phenol:chloroform:isoamylalcohol $(25: 24: 1, \mathrm{v} / \mathrm{v})$ which was centrifuged at $12,000 \mathrm{rpm}$ and $4{ }^{\circ} \mathrm{C}$ for $10 \mathrm{~min}$. Isopropanol $(0.6 \times)$ was mixed with the aqueous phase, and centrifuged at $12,000 \mathrm{rpm}$ and $4{ }^{\circ} \mathrm{C}$ for $10 \mathrm{~min}$. The DNA pellets were vacuum dried, and then dissolved in Tris buffer $[10 \mathrm{mM}$ Tris- $\mathrm{HCl}$, and $1 \mathrm{mM}$ EDTA (pH 7.5)].

\section{PCR analysis}

The small subunit rRNA gene of each sample's culture DNA was amplified using $16 \mathrm{~S}$ rRNA Universal primers. The PCR amplification reaction mixture of $50 \mu \mathrm{l}$ contained $4 \mu \mathrm{l}$ bacterial DNA (nearly $200 \mathrm{ng}$ ), $1 \mu \mathrm{l}$ Taq-DNA polymerase, $5 \mu \mathrm{l}$ of Taq buffer, $5 \mu \mathrm{l}$ of $2 \mathrm{mM}$ dNTP mix, $5 \mu$ of forward

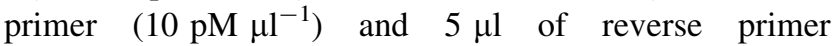
$\left(10 \mathrm{pM} \mu \mathrm{l}^{-1}\right)$. Amplification was carried out in a Bio-Rad thermo cycler run for 30 cycles. In each cycle denaturation was done at $94{ }^{\circ} \mathrm{C}$ for $20 \mathrm{~s}$, annealing at $48{ }^{\circ} \mathrm{C}$ for $20 \mathrm{~s}$ and extension was done at $72{ }^{\circ} \mathrm{C}$ for $40 \mathrm{~s}$ and a final extension was carried out for $5 \mathrm{~min}$ at $72{ }^{\circ} \mathrm{C}$ at the end of all 30 cycles. The amplified DNA fragment of approximately 1,542 bp was separated on a $1 \%$ agarose gel and purified by Qiagen spin columns (Mullis 1990; Barlett and Stirling 2003).
16S rRNA gene sequencing and phylogenetic tree construction

For 16S rRNA gene sequencing, DNA was prepared using the Mo Bio microbial DNA isolation kit (Mo Bio Laboratories Inc., Solano Beach, CA, USA) and sequenced as described previously (Lane 1991). The 1,502 nucleotides of $16 \mathrm{~S}$ rRNA gene sequence of the isolate were subjected to BLAST sequence similarity search (Altschul et al. 1990) and EzTaxon (Chun et al. 2007) to identify the nearest taxa. All the 16S rRNA gene sequences belonging to the family "Bacillaceae" were downloaded from the database (http:// www.ncbi.nlm.nih.gov), aligned using the CLUSTAL_X program (Thompson et al. 1997) and the alignment corrected manually. Phylogenetic trees were constructed using two tree-making algorithms, the maximum likelihood (ML) using the PhyML program (Guindon and Gascuel 2003) and Neighbor joining method (Saitou and Nei 1987) using the PHYLIP package, version 3.5 (Felsenstein 1993) and the resultant tree topologies were evaluated by bootstrap analysis based on 1,000 resamplings using the SEQBOOT and CONSENSE programs in the PHYLIP package. Pairwise evolutionary distances were computed using DNADIST program with the Kimura 2-parameter model as developed by Kimura (1980).

\section{Phenotypic characterization of novel Bacillus sp. PU-7}

Cell morphology and motility were studied using a light microscope. Motility was assessed on TSA medium containing $1^{-1}$ pancreatic digest of casein $(17 \mathrm{~g})$, papaic digest of soyabean meat ( $3 \mathrm{~g})$, sodium chloride $(5 \mathrm{~g})$, dipotassium hydrogen phosphate $(2.5 \mathrm{~g})$, dextrose $(2.5 \mathrm{~g})$ and agar $(0.4 \mathrm{~g})$. Growth at different temperatures, salt tolerance, biochemical characteristics, carbon assimilation, $\mathrm{H}_{2} \mathrm{~S}$ production and the sensitivity of the culture to different antibiotics were determined by previously described methods (Lanyi 1987; Smibert and Krieg 1994). Biochemical characteristics were also double checked with $\mathrm{Hi}_{25}^{\mathrm{TM}}$ Enterobacteriaceae identification kit (Cat \#KB003) and HiCarbohydrate $^{\mathrm{TM}}$ kit parts A, B and C (Cat \#KB009 of HiMedia, Mumbai, India) according to the manufacturer's protocol. Growth of $\mathrm{PU}^{\mathrm{T}}$ at different $\mathrm{pHs}$ was checked on NA medium buffered either with citric acid- $\mathrm{NaOH}$ (for $\mathrm{pH}$ 5 and 6), phosphate (for $\mathrm{pH} 7$ and 8), glycine- $\mathrm{NaOH}$ (for pH 9 and 10) or Tris buffer (for pH 11 and 12).

\section{Production of IAA from Bacillus sp. PU-7}

IAA production was detected as described by Brick et al. (1991). Bacillus culture was grown for $48 \mathrm{~h}$ on the respective media at $36{ }^{\circ} \mathrm{C}$. Well-grown cultures were centrifuged at $3,000 \mathrm{rpm}$ for $30 \mathrm{~min}$. The supernatant 
(2 ml) was mixed with two drops of orthophosphoric acid and $4 \mathrm{ml}$ of the Salkowski reagent $(50 \mathrm{ml}, 35 \%$ of perchloric acid, $1 \mathrm{ml} 0.5 \mathrm{M} \mathrm{FeCl}_{3}$ solution). Development of pink color indicates IAA production.

\section{Siderophore production from Bacillus sp. PU-7}

Siderophore production was detected by Schwyn and Neilands (1987) using blue agar plates containing the dye chrome azurol S. An orange halo around the colony is indicative of siderophore production.

Phosphate solubilization of Bacillus sp. PU-7

For phosphate solubilization assay, a medium containing $2 \mathrm{~g}$ yeast extract, $20 \mathrm{~g}$ glucose, $2 \mathrm{~g}$ tri calcium phosphate, $60 \mathrm{mg}$ actidione, and $15 \mathrm{~g}$ agar mixed with $1,000 \mathrm{ml}$ water, adjusted to $\mathrm{pH} 7$, was used. A loopful inoculum of strain Bacillus sp. PU-7 was placed in the center of petri dishes containing the media and incubated at $28{ }^{\circ} \mathrm{C}$ for 5 days. Bacterial colony forming clear zone was considered as phosphate solubilizer (Rosas et al. 2006).

Biochemical analysis of cotton plants inoculated with Bacillus sp. PU-7

\section{Extraction and analysis of total protein}

The total protein was extracted by homogenizing $0.5 \mathrm{~g}$ plant tissue in $10 \mathrm{ml}$ of $0.2 \mathrm{M}$ perchloric acid. The homogenate was centrifuged at 5,000 g for $10 \mathrm{~min}$ at $24{ }^{\circ} \mathrm{C}$. Ethanol-ether-chloroform $(2: 2: 1 ; \mathrm{v} / \mathrm{v} / \mathrm{v})$ solvent mixture was used twice for the extraction of the pellet. To the residue, $0.2 \mathrm{M} \mathrm{NaOH}$ was added and left overnight. The supernatant was used for total protein estimation (Lowry et al. 1951).

\section{Estimation of sugars}

Total soluble sugar was analyzed by heating $1 \mathrm{~g}$ of the plant tissue with $0.2 \%$ anthrone reagent and reading the intensity at $625 \mathrm{~nm}$ using UV-VIS spectrophotometer (Spectronic D20) (Mahadevan and Shridhar 1986).

\section{Estimation of proline}

Proline estimation was carried out as described by Bates et al. (1973). Fresh mass of $0.5 \mathrm{~g}$ leaf tissue was taken and homogenized in $5 \mathrm{ml}$ of $3 \%(\mathrm{w} / \mathrm{v})$ sulphosalicylic acid. The residue was removed by centrifugation at $5,000 \mathrm{rpm}$ for $10 \mathrm{~min}$ and the supernatant was filtered through Whatman \# 2 filter paper. The filtrate was mixed with an equal volume of ninhydrin and glacial acetic acid and incubated at $95{ }^{\circ} \mathrm{C}$ for $1 \mathrm{~h}$. The reaction was terminated by placing in an ice bath for about $30 \mathrm{~min}$ and then extracted with $4 \mathrm{ml}$ toluene by mixing vigorously for $15 \mathrm{~s}$. The toluene phase containing the chromophore was aspirated, warmed to room temperature for $10 \mathrm{~min}$ and the proline content was determined colorimetrically and expressed in $\mathrm{mg} \mathrm{g}^{-1}$.

\section{Estimation and extraction of chlorophyll}

Chlorophyll pigment was extracted from $1 \mathrm{~g}$ of cotton leaves inoculated with Bacillus sp. PU-7 in $80 \%$ acetone and estimated as described by Harborne (1973). The extracts were filtered in dark. OD values of filtrate were measured at 650 and $663 \mathrm{~nm}$ in UV-VIS spectrophotometer. The amount of total chlorophyll was calculated by Arnon's formula.

\section{Phytohormone production from cotton plants inoculated} with Bacillus sp. PU-7

Estimation of IAA One gram of leaf sample was crushed with $1 \mathrm{ml}$ of phosphate buffer. Samples were centrifuged and two drops of perchloric acid were added to the supernatant to make up the volume to $2 \mathrm{ml}$ with Salkowski reagent (i.e., $2 \% 0.5 \mathrm{M} \mathrm{FeCl}_{3}$ in $35 \%$ perchloric acid). OD values were taken after $25 \mathrm{~min}$ at $530 \mathrm{~nm}$ by UV-VIS spectrophotometer. Standard graph was prepared by plotting concentration of IAA in $\mu \mathrm{g} \mathrm{ml}^{-1}$ vs optical density at $530 \mathrm{~nm}$.

Collection of soil samples from different agricultural fields of cotton Four different soil samples were collected from cotton fields of Mahabubnagar District, viz., shallow black soil from Malleboinpally, red soil from Makthal, deep black soil from Kalwakurthy and sandy soil from Narayanpet.

Physico-chemical characteristics of soil samples of agricultural fields of cotton Soil available nitrogen was estimated by alkaline potassium permanganate method (Subbiah and Asija 1956), available phosphorous was determined by Bray and Kurtz (1945) and potassium determined by flame photometrically (Jackson 1973).

Statistical analysis

A statistical analysis was performed using a statistical software SPSS for Windows version 17.0. ANOVA, $t$ test was applied on subjects to know the significance of multiple mean differences and mean difference, respectively. $P$ values are significant at $5 \%$ level (or 95 confidence level). 


\section{Results}

Isolation of novel PGPR Bacillus sp. PU-7

The main aim of present investigation is to isolate novel and efficient Bacillus species from cotton rhizosphere soil near boy's hostel in Palamuru University. Seven species of Bacillus were isolated, among them Bacillus strain-7 has shown maximum growth of plant with 8 cultivars of cotton from 17 cultivars tested (Table 1). We subsequently named the isolated strain as Bacillus sp. PU-7 (Fig. 1) based on 16S rRNA gene sequence.

\section{Description of novel Bacillus sp. PU-7}

Cells are Gram-positive, motile with single mono-polar flagellum, rod-shaped $(0.6-0.7 \mu \mathrm{m}$ in width and $1.6-2 \mu \mathrm{m}$ in length) and occur singly and multiply by binary fission. Colonies on nutrient agar are circular, 1-2 $\mathrm{mm}$ in diameter, smooth, cream in color, opaque, crateri form and entire. Cells grow from 18 to $40{ }^{\circ} \mathrm{C}$ with an optimum temperature of $37^{\circ} \mathrm{C}$ and tolerate up to $9.0 \% \mathrm{NaCl}(\mathrm{w} / \mathrm{v})$. Growth occurs in a $\mathrm{pH}$ range of $7-10$, designated strain $\mathrm{PU} 1^{\mathrm{T}}$ was isolated from cotton rhizosphere soil near the boy's hostel of Palamuru University, Mahabubnagar district, Andhra Pradesh, India. Cells of the strain $\mathrm{PU} 1^{\mathrm{T}}$ are positive for catalase, oxidase, phosphatase, lipase and urease and negative for gelatinase, amylase, protease, cellulase, lysine decarboxylase and ornithine decarboxylase (Table 2). The

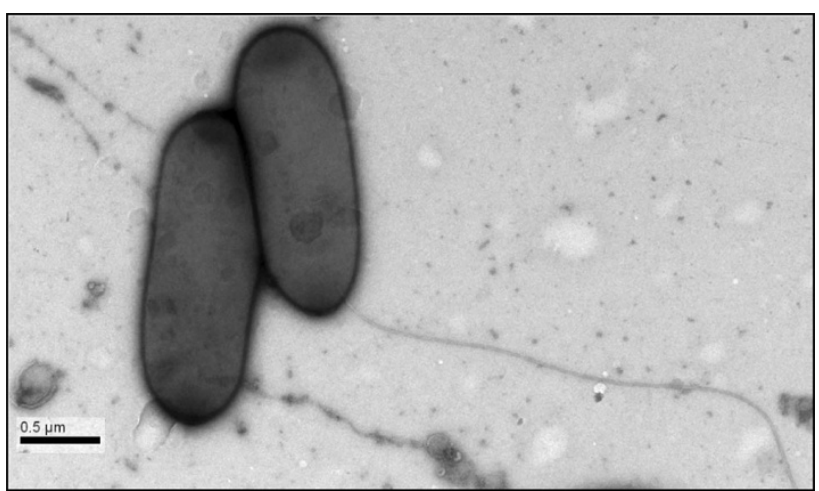

Fig. 1 Electron micrograph of negatively stained cells of Bacillus sp. PU-7. Bar $0.5 \mu \mathrm{m}$

16S rRNA gene sequence analysis indicated Bacillus psychrodurans and Bacillus psychrotolerans members of family "Bacillaceae" (phylum "Firmicutes") are the closest related species with a sequence similarity of 96.0-96.2 \%. Other members of the family "Bacillaceae" had sequence similarities of $<96.0 \%$. Based on the abovementioned phenotypic and phylogenetic characteristics, strain PU-7 is proposed as the representative of a new species, novel Bacillus sp. PU-7 (Fig. 2).

Bacillus sp. PU-7 was tested for plant growth promoting characteristics (Table 3). Eight cultivars which have shown maximum growth with Bacillus sp. PU-7 (Fig. 3) were analyzed for biochemical characters and phytohormone production. Among eight cultivars of cotton, Mahyco has

Table 1 Plant growth parameters of 17 cotton cultivars (60 days old) with 7 different isolates of Bacillus

\begin{tabular}{|c|c|c|c|c|c|c|c|c|}
\hline Strain/seed variety & Control & Strain-1 & Strain-2 & Strain-3 & Strain-4 & Strain-5 & Strain-6 & Strain-7 \\
\hline Mahyco & + & ++ & + & ++ & + & + & + & +++ \\
\hline Ajeet & + & + & + & - & ++ & + & + & ++ \\
\hline Rashi & + & - & ++ & + & - & ++ & - & +++ \\
\hline Tulasi & + & ++ & + & + & + & - & + & ++ \\
\hline Marvel & + & + & - & - & ++ & - & + & +++ \\
\hline Bunni & + & + & ++ & - & - & + & ++ & ++ \\
\hline PCH-125 & + & ++ & + & + & ++ & + & - & ++ \\
\hline Nusun & + & ++ & - & + & + & ++ & ++ & +++ \\
\hline Kaveri & + & - & ++ & + & + & + & + & +++ \\
\hline Raj seeds & + & + & + & - & + & + & + & +++ \\
\hline Super seeds & \pm & + & + & + & + & + & ++ & + \\
\hline Veda & + & + & - & ++ & + & + & + & ++ \\
\hline Brahmaputra & \pm & + & + & + & + & + & + & + \\
\hline S99Bt & \pm & + & + & + & + & + & - & ++ \\
\hline Obama Bt & + & + & + & - & + & - & + & +++ \\
\hline Bunni seeds & + & - & ++ & ++ & - & ++ & + & ++ \\
\hline Sunny (NCS-108) & + & + & + & ++ & + & ++ & + & +++ \\
\hline
\end{tabular}

+++ plant growth above $40 \mathrm{~cm},++$ plant growth below $30 \mathrm{~cm},+$ plant growth below $20 \mathrm{~cm}, \pm$ plant growth below $15 \mathrm{~cm},-$ plant growth below $10 \mathrm{~cm}$ 
shown maximum levels of IAA, proteins sugars, chlorophyll, and minimum content of proline and Sunny (NCS108) has shown minimum levels of IAA, proteins, sugars chlorophyll and high level of proline (Table 4).

Efficacy of novel Bacillus sp. PU-7 as a PGPR

Based on the above discussed results, it was apparent that Bacillus sp. PU-7 could be as used as a PGPR in bioformulation of poor soils that support least plant growth. We have collected four soil samples that were known to be poor for plant growth as described in "Materials and methods" and NPK and trace elements were determined (Table 5). These soil samples were inoculated with Bacillus sp. PU-7 and uninoculated sample was taken as control. Mahyco cultivar was grown in these 4 different soils for a period of 90 days in order to see the efficiency of novel isolate in natural conditions. Mahyco growth (physical growth parameters, phytohormone production and biochemical characteristics) was good in all soil types, but maximum growth was recorded in deep black soil followed by shallow black soil and minimum growth was observed in sandy soil followed by red soil (Tables 6,7 ).

\section{Discussion}

Rhizosphere is defined as the soil influenced by roots, bacterial species that carry out functions which promote growth of plants. These bacteria are designated as PGPR (Martínez-Viveros et al. 2010). Pseudomonas and Bacillus genera are the most commonly investigated PGPR, and often the dominating bacterial groups in the rhizosphere (Morgan et al. 2005). Bacillus species have been reported to promote the growth of a wide range of plants (De Freitas et al. 1997; Kokalis-Burelle et al. 2002). Trials with rhizosphere-associated plant growth promoting $\mathrm{N}_{2}$-fixing and phosphate solubilising Bacillus species indicated yield increase in sorghum (Broadbent et al. 1977), maize (Pal 1998), rice (Sudha et al. 1999), sugar beet (Cakmakci et al. 1999), barley (Sahin et al. 2004) and apples (Aslantas et al. 2007).

McSpadden Gardener (2004) and Ona et al. (2003) demonstrated the enhancement of plant growth by Bacillus and Paenibacillus. They promote plant growth by the solubilization of phosphorus and production of phytohormones, such as IAA (Lal and Tabacchioni 2009). Among PGPR species, Azospirillum is one of the best studied IAA

Table 2 Characteristics that differentiate the strain PU-7 with the closely related species of the genus Bacillus

\begin{tabular}{|c|c|c|c|c|}
\hline Characteristic & PU-7 & $\begin{array}{l}\text { Bacillus psychrodurans } \\
\text { DSM } 11713^{\mathrm{T}}\end{array}$ & $\begin{array}{l}\text { Bacillus psychrotolerans } \\
\text { DSM } 11706^{T}\end{array}$ & $\begin{array}{l}\text { Bacillus insolitus } \\
\text { DSM } 5^{\mathrm{T}}\end{array}$ \\
\hline Cell morphology & Rods & Rods & Regular rods & Rods \\
\hline Cell size $(\mu \mathrm{m})$ & $0.6-0.7 \times 1.6-2$ & $0.5-0.6 \times 2-5$ & $0.4-1 \times 2-7$ & $1.0-1.5 \times 1.6-2.7$ \\
\hline Nitrate reduction & - & + & - & - \\
\hline Salinity tolerance $(\%)$ & 9 & 5 & 3 & 2 \\
\hline Temperature range $\left({ }^{\circ} \mathrm{C}\right)$ & $18-40$ & -2 to 30 & -2 to 30 & $0-25$ \\
\hline Anaerobic growth & - & + & - & - \\
\hline$\beta$-Galactosidase & - & $\mathrm{w}$ & - & + \\
\hline Lysine decarboxylase & - & $\mathrm{w}$ & w & + \\
\hline Ornithine decarboxylase & - & + & + & + \\
\hline Nitrate reduction & - & + & - & + \\
\hline \multicolumn{5}{|l|}{ Hydrolysis of } \\
\hline DNA & - & + & + & + \\
\hline Gelatin & - & + & - & + \\
\hline Starch & - & + & + & - \\
\hline Tween 60 & + & $\mathrm{w}$ & + & - \\
\hline Urea & + & - & - & $\mathrm{w}$ \\
\hline \multicolumn{5}{|l|}{ Acid production from } \\
\hline D-Glucose, & + & + & w & - \\
\hline L-Arabinose, & - & w & w & - \\
\hline D-Xylose & + & w & w & - \\
\hline D-Mannitol & + & + & w & - \\
\hline \multicolumn{5}{|l|}{ Utilization of } \\
\hline Citrate & + & - & - & + \\
\hline
\end{tabular}

+ positive, - negative, $w$ weak 
Fig. 2 Phylogenetic tree based on 16S rRNA gene sequences showing the relationship of Bacillus sp. PU-7 with the species of the genus Bacillus. Phylogenetic tree was constructed using the maximum likelihood method. Numbers at nodes are bootstrap values. The bar represents 0.02 substitutions per alignment position

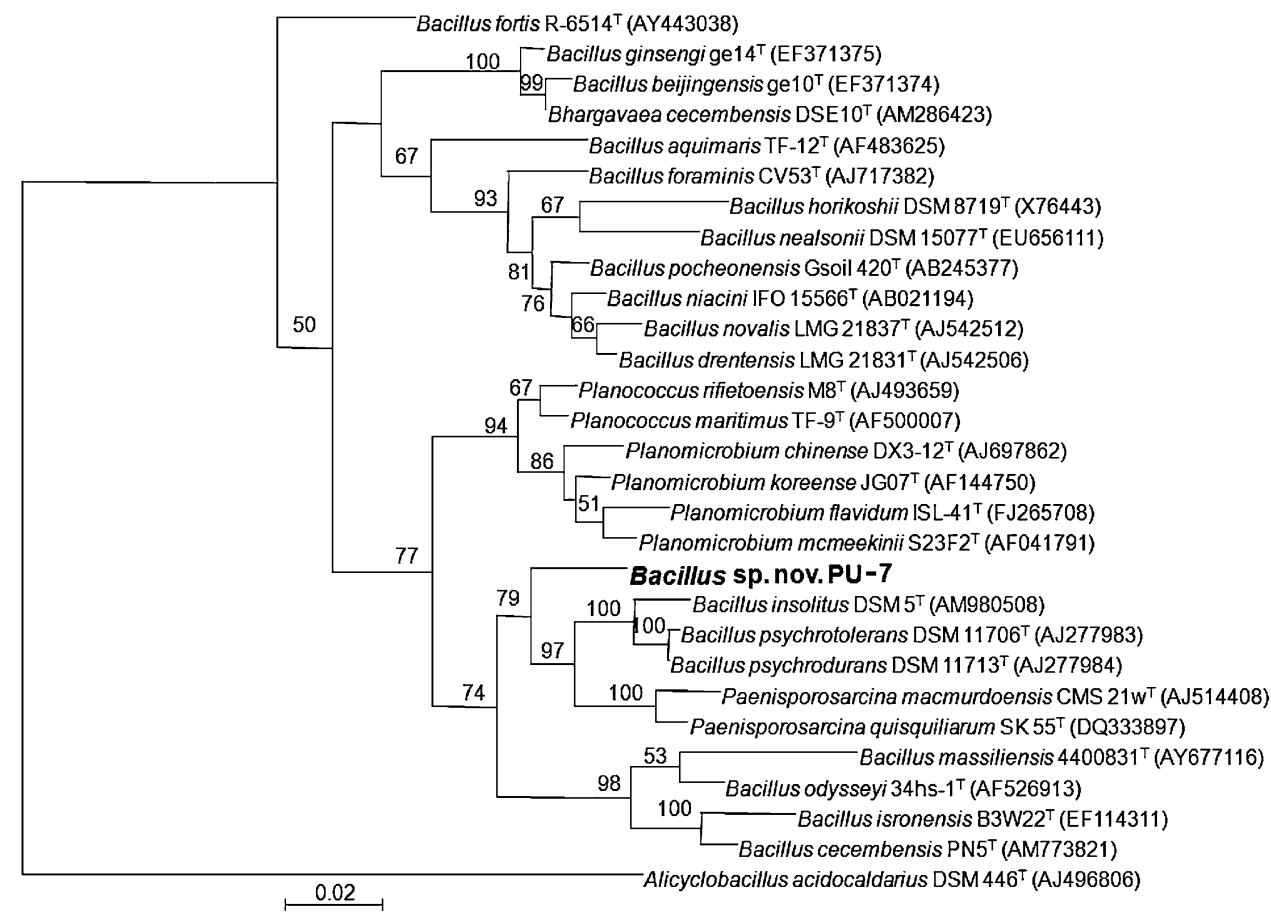

Table 3 Plant growth promoting characteristics of novel Bacillus sp. PU-7

\begin{tabular}{ll}
\hline Characteristics & Bacillus sp. PU-7 \\
\hline Phosphate solubilization test & + \\
IAA production & + \\
Siderophore production & + \\
\hline
\end{tabular}

producers (Dobbelaere et al. 1999). Other IAA producing bacteria belonging to Aeromonas (Halda-Alija 2003), Azotobacter (Ahmad et al. 2008), Bacillus (Swain et al. 2007), Burkholderia (Halda-Alija 2003), Enterobacter (Shoebitz et al. 2009), Pseudomonas (Hariprasad and Niranjana 2009) and Rhizobium (Ghosh et al. 2008) genera have been isolated from different rhizosphere soils. Inoculation with IAA producing PGPR has been used to stimulate seed germination, to accelerate root growth and modify the architecture of the root system, and to increase the root biomass. In recent studies, Tsavkelova et al. (2007) have extended beyond individual strains as inoculants and reported an increase in the germination of orchid seeds (Dendrobium moschatum) inoculated with Sphingomonas sp. and IAA producing Mycobacterium sp. In addition to stimulating root growth, IAA producing bacteria can also be used to stimulate tuber growth. Swain et al. (2007) reported a positive effect of $B$. subtilis IAA producing strains on the edible tubercle Dioscorea rotundata $\mathrm{L}$. in one of their studies. They applied a suspension of $B$. subtilis on the surface of the plants, which resulted in an increase in stem and root length, increased fresh weight of the stem and root, an increase in the root:stem ratio and increased numbers of sprouts as compared with non-inoculated plants. Phytohormones such as IAA may indirectly improve $\mathrm{P}$ acquisition by plants by increasing root growth
Fig. 3 Eight different cultivars of cotton inoculated with novel Bacillus sp. PU-7

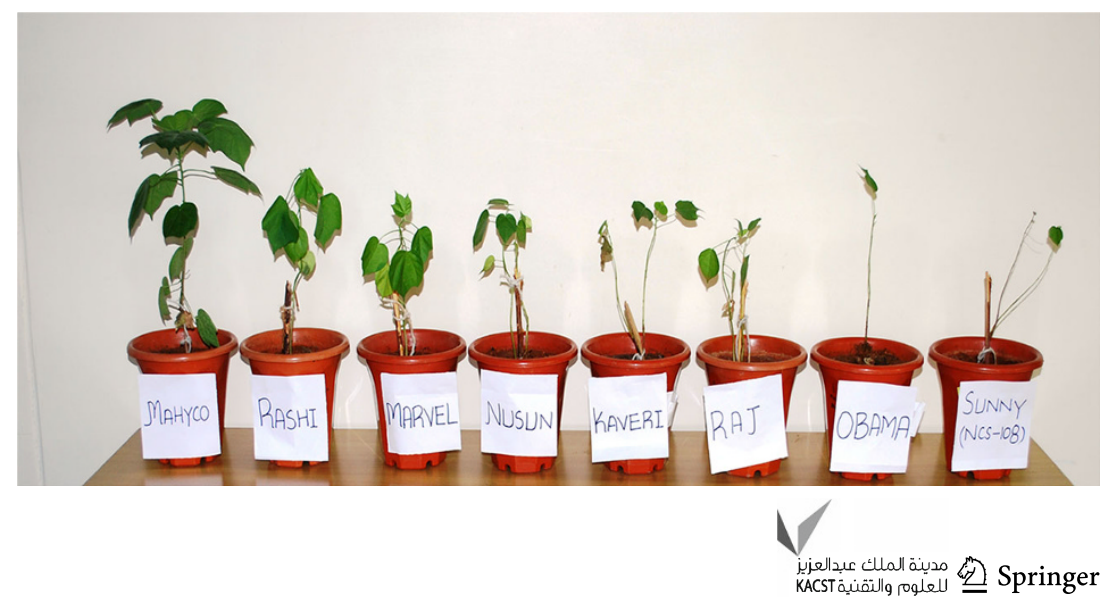


Table 4 Phytohormone and biochemical production of 8 cotton cultivars (60 days old) inoculated with Bacillus sp. PU-7 (mean \pm SE)

\begin{tabular}{llllll}
\hline Cultivar & IAA $\left(\mu \mathrm{g} \mathrm{g}^{-1}\right)$ & Proteins $\left(\mathrm{mg} \mathrm{g}^{-1}\right)$ & Sugars $\left(\mathrm{mg} \mathrm{g}^{-1}\right)$ & Chlorophyll $\left(\mathrm{mg} \mathrm{g}^{-1}\right)$ & ${\text { Proline }\left(\mu \mathrm{g} \mathrm{g}^{-1}\right)}^{2}$ \\
\hline Mahyco & $749.67 \pm 22.81$ & $270 \pm 11.55$ & $129 \pm 5.86$ & $156.67 \pm 6.67$ & $340 \pm 30.55$ \\
Rashi & $657 \pm 23.16$ & $218.34 \pm 15.90$ & $140.66 \pm 15.45$ & $134 \pm 8.72$ & $350.67 \pm 25.57$ \\
Marvel & $658.34 \pm 13.64$ & $223 \pm 4.62$ & $118 \pm 8.39$ & $136.67 \pm 14.53$ & $330.00 \pm 25.17$ \\
Nusun & $634 \pm 20.23$ & $208 \pm 15.62$ & $122.67 \pm 11.85$ & $113.33 \pm 6.67$ & $325.33 \pm 16.38$ \\
Kaveri & $561 \pm 10.69$ & $175 \pm 8.66$ & $101.67 \pm 10.14$ & $113.33 \pm 8.82$ & $343.34 \pm 29.06$ \\
Raj seeds & $536.34 \pm 14.84$ & $165 \pm 10.41$ & $129 \pm 12.42$ & $89.67 \pm 5.78$ & $258.33 \pm 13.64$ \\
Obama & $502 \pm 13.00$ & $140 \pm 2.31$ & $126.67 \pm 17.64$ & $106.67 \pm 14.53$ & $240 \pm 15.28$ \\
Sunny & $431 \pm 20.60$ & $124 \pm 3.06$ & $103.33 \pm 6.67$ & $156.67 \pm 8.82$ & $277 \pm 11.36$ \\
$P$ value & $0.0001 * *$ & $0.0001 * *$ & 0.24 & $0.05 *$ & $0.05 *$ \\
\hline
\end{tabular}

* Significant; ** Highly significant

Table 5 Physico-chemical characteristics and available sulphur and micronutrients content of four agricultural soils of Mahabubnagar dist

\begin{tabular}{|c|c|c|c|c|c|c|c|c|c|c|}
\hline GPS location & Soil type & $\mathrm{pH}$ & $\mathrm{N}$ & $\mathrm{P}$ & $\mathrm{K}$ & $S$ & $\mathrm{Fe}$ & Mn & $\mathrm{Zn}$ & $\mathrm{Cu}$ \\
\hline Malleboinpally lati 78.13388 , long 16.77465 & Shallow black soil & 8.0 & 220.10 & 95.62 & 118.42 & 8.8 & 2.27 & 24.15 & 0.26 & 0.25 \\
\hline Makthal lati 77.527836 , long 16.724264 & Red soil & 7.0 & 199.47 & 86.19 & 103.69 & 11.2 & 5.32 & 26.31 & 0.98 & 0.24 \\
\hline Kalwakurthy lati 78.492231 , long 16.66739 & Deep black & 8.0 & 248.95 & 103.26 & 132.14 & 8.2 & 2.24 & 32.123 & 0.35 & 0.51 \\
\hline Narayanpet lati 77.49425 , long 16.74231 & Sandy soil & 8.0 & 192.96 & 79.87 & 98.78 & 3.2 & 0.13 & 9.48 & 0.05 & 0.03 \\
\hline
\end{tabular}

NPK in $\mathrm{kg} \mathrm{ha}^{-1}$, sulphur and micronutrients in ppm

Table 6 Plant growth parameters, phytohormone production and biochemical characteristics of Mahyco cotton cultivar in four different agricultural soils of Mahabubnagar district

\begin{tabular}{|c|c|c|c|c|c|c|c|c|}
\hline \multirow[t]{2}{*}{ Soil type } & \multirow[t]{2}{*}{ Location } & \multirow[t]{2}{*}{ Combination } & \multicolumn{2}{|c|}{ Height of the plant $(\mathrm{cm})$} & \multicolumn{2}{|c|}{ Plant fresh weight $(\mathrm{g})$} & \multicolumn{2}{|c|}{ Plant dry weight (g) } \\
\hline & & & $S$ & $R$ & $S$ & $R$ & $S$ & $R$ \\
\hline \multirow{2}{*}{$\begin{array}{l}\text { Shallow } \\
\text { black soil }\end{array}$} & \multirow[t]{2}{*}{ Malleboinpally } & Control & $22.4 \pm 0.00$ & $11.3 \pm 0.00$ & $3.9 \pm 0.00$ & $1.45 \pm 0.00$ & $0.52 \pm 0.00$ & $0.4 \pm 0.00$ \\
\hline & & $\mathrm{M}+\mathrm{BP}$ & $33.2 \pm 0.52 *$ & $22.3 \pm 0.34^{*}$ & $4.52 \pm 0.014 *$ & $1.74 \pm 0.04 *$ & $0.67 \pm 0.028 *$ & $0.56 \pm 0.014 *$ \\
\hline \multirow[t]{2}{*}{ Red soil } & \multirow[t]{2}{*}{ Makthal } & Control & $20.2 \pm 0.00$ & $11.0 \pm 0.00$ & $3.85 \pm 0.00$ & $1.4 \pm 0.00$ & $0.5 \pm 0.00$ & $0.39 \pm 0.00$ \\
\hline & & $\mathrm{M}+\mathrm{BP}$ & $30.7 \pm 0.17^{*}$ & $20.3 \pm 0.14^{*}$ & $4.24 \pm 0.02 *$ & $1.66 \pm 0.014^{*}$ & $0.61 \pm 0.01 *$ & $0.61 \pm 0.00 *$ \\
\hline \multirow{2}{*}{$\begin{array}{l}\text { Deep black } \\
\text { soil }\end{array}$} & \multirow[t]{2}{*}{ Kalwakurthy } & Control & $25.4 \pm 0.00$ & $12.7 \pm 0.00$ & $3.99 \pm 0.00$ & $1.89 \pm 0.00$ & $0.58 \pm 0.00$ & $0.48 \pm 0.00$ \\
\hline & & $\mathrm{M}+\mathrm{BP}$ & $37.9 \pm 0.02 *$ & $23.4 \pm 0.14 *$ & $4.62 \pm 0.014 *$ & $1.95 \pm 0.025^{*}$ & $0.67 \pm 0.02 *$ & $37.9 \pm 0.02 *$ \\
\hline \multirow[t]{2}{*}{ Sandy soil } & \multirow[t]{2}{*}{ Narayanpet } & Control & $20.1 \pm 0.00$ & $10.2 \pm 0.00$ & $3.45 \pm 0.00$ & $1.34 \pm 0.00$ & $0.45 \pm 0.00$ & $0.32 \pm 0.00$ \\
\hline & & $\mathrm{M}+\mathrm{BP}$ & $30.16 \pm 0.013^{*}$ & $20.16 \pm 0.14^{*}$ & $4.20 \pm 0.00^{*}$ & $1.62 \pm 0.007 *$ & $0.61 \pm 0.007 *$ & $0.51 \pm 0.007 *$ \\
\hline
\end{tabular}

$M$ Mahyco cotton cultivar, BP Bacillus sp. PU-7, $S$ shoot, $R$ root

* Significant at 0.05

(Marschner et al. 2011). Bacillus and Paenibacillus are also able to produce endospores, which enhances their persistence and viability in soils (Lal and Tabacchioni 2009; Nicholson 2002). Yao et al. (2006) described the cotton plant crop response to B. subtilis FZB 24 experimental conditions which has increased the $31 \%$ average yield $\left(\mathrm{t} \mathrm{ha}^{-1}\right), 19 \%$ bolls/plant mean number and $11 \%$ mean plant height in $\mathrm{cm}$.

In the present investigation Bacillus sp. PU-7 which was identified based on 16S rRNA gene sequence has shown positive results for plant growth promoting characteristics such as phosphate solubilization, IAA and siderophore production.

The ability of PGPRs to convert insoluble phosphorus (P) to an accessible form is an important trait for increasing the plant yields. The fact that certain microbes are capable of dissolving relatively insoluble phosphatic compounds has opened the possibility of inducing microbial solubilization of the phosphates in the soil (Zaidi et al. 2009). Rhizobacteria solubilize the mineral $\mathrm{P}$ in the rhizosphere and hence, provided soluble $\mathrm{P}$ to the plants. The cause of the mineral $\mathrm{P}$ solubilization could probably be due to 
Table 7 Phytohormone production and biochemical characteristics of Mahyco cotton cultivar in four different agricultural soils (with mean \pm SE) of Mahabubnagar district

\begin{tabular}{|c|c|c|c|c|c|c|c|}
\hline Soil type & Location & Combination & IAA $\left(\mu \mathrm{g} \mathrm{g}^{-1}\right)$ & $\begin{array}{l}\text { Proteins } \\
\left(\mathrm{mg} \mathrm{g}^{-1}\right)\end{array}$ & $\begin{array}{l}\text { Sugars } \\
\left(\mathrm{mg} \mathrm{g}^{-1}\right)\end{array}$ & $\begin{array}{l}\text { Chlorophyll } \\
\left(\mathrm{mg} \mathrm{g}^{-1}\right)\end{array}$ & Proline $\left(\mu \mathrm{g} \mathrm{g}^{-1}\right)$ \\
\hline \multirow{2}{*}{$\begin{array}{l}\text { Shallow black } \\
\text { soil }\end{array}$} & \multirow[t]{2}{*}{ Malleboinpally } & Control & $382 \pm 0.00$ & $62 \pm 0.00$ & $77 \pm 0.00$ & $62.9 \pm 0.00$ & $520 \pm 0.00$ \\
\hline & & $\mathrm{M}+\mathrm{BP}$ & $782.67 \pm 4.24^{*}$ & $175.67 \pm 1.41 *$ & $132.33 \pm 1.41 *$ & $147.67 \pm 2.12^{*}$ & $408.33 \pm 10.21 *$ \\
\hline \multirow[t]{2}{*}{ Red soil } & \multirow[t]{2}{*}{ Makthal } & Control & $650 \pm 0.00$ & $102 \pm 0.00$ & $92.00 \pm 0.00$ & $109 \pm 0.00$ & $680 \pm 0.00$ \\
\hline & & $\mathrm{M}+\mathrm{BP}$ & $715.33 \pm 14.14 *$ & $137.67 \pm 0.71 *$ & $109.00 \pm 1.41 *$ & $113.00 \pm 1.41^{*}$ & $556.67 \pm 15.28 *$ \\
\hline \multirow[t]{2}{*}{ Deep black soil } & \multirow[t]{2}{*}{ Kalwakurthy } & Control & $700 \pm 0.00$ & $69.00 \pm 0.00$ & $87.00 \pm 0.00$ & $70.1 \pm 0.00$ & $410 \pm 0.00$ \\
\hline & & $\mathrm{M}+\mathrm{BP}$ & $811.67 \pm 10.61 *$ & $219.00 \pm 1.41^{*}$ & $151.00 \pm 1.42^{*}$ & $182.33 \pm 3.54^{*}$ & $316.67 \pm 5.77^{*}$ \\
\hline \multirow[t]{2}{*}{ Sandy soil } & \multirow[t]{2}{*}{ Narayanpet } & Control & $350 \pm 0.00$ & $58.00 \pm 0.00$ & $68.00 \pm 0.00$ & $52.3 \pm 0.00$ & $740 \pm 0.00$ \\
\hline & & $\mathrm{M}+\mathrm{BP}$ & $635.67 \pm 5.66^{*}$ & $99.00 \pm 3.54^{*}$ & $99.00 \pm 4.95 *$ & $107.33 \pm 3.54 *$ & $646.67 \pm 30.33 *$ \\
\hline
\end{tabular}

* Significant at 0.05

secretion of organic acids such as gluconic, 2-ketogluconic, oxalic, citric, acetic, malic, and succinic acid, etc. It is clear from the present results that Bacillus sp. PU-7 is a potential phosphate solubilizer.

Bacilli strains that can solubilizes $\mathrm{P}$ and produce siderophore and IAA have widely been reported (Raddadi et al. 2008; Trivedi and Pandey 2008) and have been shown to promote the growth of maize and wheat (Beneduzi et al. 2008; Trivedi and Pandey 2008).

Efficient and potential isolate Bacillus sp. PU-7 has shown maximum growth and high levels of IAA, proteins, sugars, chlorophyll and proline with Mahyco cultivar. This novel isolate has shown tremendous growth in different agricultural soil types, but maximum growth was observed in black soil in terms of plant growth, phytohormonal production and biochemical characteristics.

\section{Conclusion}

Novel Bacillus sp. PU-7 is an efficient isolate which is enhancing good growth of cotton plants in terms of physical growth parameters, phytohormonal, biochemical properties and supports plant growth in deep black soils followed by shallow black soils. Hence, this novel species with the biotechnological potential as a biofertilizer, with respect to their plant growth promoting properties can be used as bioinoculant in the cotton fields. It is concluded from present findings that efficient novel isolate can be used as a bioinoculant/PSB in different agricultural soils of cotton.

Acknowledgments The authors are thankful to Prof. G. Bagyanarayana, Vice Chancellor and Prof. K. Venkatachalam, Registrar, Palamuru University for the constant support and encouragement.

Conflict of interest The authors declare that they do not have any conflict of interest.
Open Access This article is distributed under the terms of the Creative Commons Attribution License which permits any use, distribution, and reproduction in any medium, provided the original author(s) and the source are credited.

\section{References}

Ahmad F, Ahmad I, Khan MS (2008) Screening of free-living rhizospheric bacteria for their multiple plant growth promoting activities. Microbiol Res 163:173-181

Aloni R et al (2006) Role of cytokinin and auxin in shaping root architecture: regulating vascular differentiation, lateral root initiation, root apical dominance and root gravitropism. Ann Bot 97:883-893

Altschul S, Gish W, Myers EW, Lipman DJ (1990) Basic local alignment search tool. Mol Biol 215:403-410

Aslantas R, Cakmakci R, Sahin F (2007) Effect of plant growth promoting rhizobacteria on young apple trees growth and fruit yield under orchard conditions. Sci Hortic 111:371-377

Barlett JM, Stirling D (2003) A short history of the polymerase chain reaction. Methods Mol Biol 226:3-6

Bates LE, Waldren RP, Teare FD (1973) Rapid determination of free proline for water stress studies. Plant Soil 39:205-207

Bell CR et al (1995) Endophytic bacteria in grapevine. Can J Microbiol 41:46-53

Beneduzi A, Peres D, Da Costa PB, Bodanese Zanettini MH, Passaglia LM (2008) Genetic and phenotypic diversity of plantgrowth-promoting bacilli isolated from wheat fields in southern Brazil. Res Microbiol 159:244-250

Berg $\mathrm{G}$ et al (2005) Impact of plant species and site on rhizosphereassociated fungi antagonistic to Verticillium dahliae Kleb. Appl Environ Microbiol 71:4203-4213

Bloemberg GV, Lugtenberg BFJ (2001) Molecular basis of plant growth promotion and biocontrol by rhizobacteria. Curr Opin Plant Biol 4:343-350

Bottini R, Cassan F, Picolli P (2004) Gibberellin production by bacteria and its involvement in plant growth promotion. Appl Microbiol Biotechnol 65:497-503

Bray R, Kurtz LT (1945) Determination of total organic and available forms of phosphorus in soils. Soil Sci 59:39-46

Brick JM, Bostock RM, Silverstone SE (1991) Rapid in situ assay for indole acetic acid production by bacteria immobilized on nitrocellulose membrane. Appl Environ Microbiol 57:535-538 
Broadbent P, Bake KF, Franks N, Holland J (1977) Effect of Bacillus sp. on increased growth of seedlings in steamed and in non treated soil. Phytopathology 67:1027-1034

Cakmakci R, Kantar F, Algur OF (1999) Sugar beet and barley yields in relation to Bacillus polymyxa and Bacillus megaterium var. phosphaticum inoculation. J Plant Nutr Soil Sci 162:437-442

Choudhary DK, Johri BN (2008) Interactions of Bacillus sp. and plants-with special reference to induced systemic resistance (ISR). Microbial Res 164:493-513

Chun J et al (2007) Ez Taxon: a web based tool for the identification of prokaryotes based on 16S ribosomal RNA gene sequences. Int J Syst Evol Microbiol 57:2259-2261

Costacurta A, Vanderleyden J (1995) Synthesis of phytohormones by plant-associated bacteria. Crit Rev Microbiol 21:1-18

Crowley DE (2006) Microbial siderophores in the plant rhizosphere. In: Barton LL, Abadía J (eds) Iron nutrition in plants and rhizospheric microorganisms. Springer, Netherlands, pp 169-198

Crowley DE, Gries D (1994) Modeling of iron availability in the plant rhizosphere. In: Manthey JA, Crowley DE, Luster DG (eds) Biochemistry of metal micronutrients in the rhizosphere. Lewis Publishers, Boca Raton, pp 199-224

De Freitas JR, Banerjee MR, Germida JJ (1997) Phosphate-solubilizing rhizobacteria enhance the growth and yield but not phosphorus uptake of canola (Brassica napus L.). Biol Fertil Soil 24:358-364

Dobbelaere S, Croonenborghs A, Thys A, Vande Broek A, Vanderleyden J (1999) Phytostimulatory effect of Azospirillum brasilense wild type and mutant strains altered in IAA production on wheat. Plant Soil 212:155-164

Felsenstein J (1993) PHYLIP (phylogeny inference package), version 3.5.1. Department of Genome Sciences, University of Washington, Seattle

Fuentes-Ramírez LE, Caballero-Mellado J (2006) Bacterial biofertilizers. In: Siddiqui ZA (ed) PGPR: biocontrol and biofertilization. Springer, Netherlands, pp 143-172

Ghosh S, Sengupta C, Maiti TK, Basu PS (2008) Production of 3-indolylacetic acid in root nodules and culture by a Rhizobium species isolated from root nodules of the leguminous pulse Phaseolus mungo. Folia Microbiol 53:351-355

Glick BR, Penrose DM, Li J (1998) A model for the lowering of plant ethylene concentrations by plant growth-promoting bacteria. J Theor Biol 190:63-68

Guindon S, Gascuel O (2003) A simple, fast, and accurate algorithm to estimate large phylogenies by maximum likelihood. Syst Biol 52:696-704

Gutierrez-Manero FJ, Ramos B, Probanza A, Mehouachi J, Talon M (2001) The plant growth promoting rhizobacteria Bacillus pumilus and Bacillus licheniformis produce high amounts of physiologically active gibberellins. Physiol Plant 111:206-211

Halda-Alija L (2003) Identification of indole-3-acetic acid producing freshwater wetland rhizosphere bacteria associated with Juncus effusus L. Can J Microbiol 49:781-787

Harborne JB (1973) Phytochemical methods. Chapman and Hall Ltd, London

Hariprasad P, Niranjana SR (2009) Isolation and characterization of phosphate solubilizing rhizobacteria to improve plant health of tomato. Plant Soil 316:13-24

Idris EES et al (2004) Use of Bacillus subtilis as biocontrol agent. 6. Phytohormone action of culture filtrate prepared from plant growth promoting Bacillus amyloliquefaciens FZB24, FZB42, FZB45 and Bacillus subtilis FZB37. J Plant Dis Prot 111:583-597

Idris EES, Iglesias DJ, Talon M, Borriss R (2007) Tryptophandependent production of indole-3-acetic acid (IAA) affects level of plant growth promotion by Bacillus amyloliquefaciens FZB42. Mol Plant Microbe Interact 20:619-626

Jackson ML (1973) Soil chemical analysis. Prentice Hall of India Pvt. Ltd., New Delhi

Kimura M (1980) A simple method for estimating evolutionary rates of base substitutions through comparative studies of nucleotide sequences. J Mol Evol 16:111-120

Kokalis-Burelle N, Vavrina CS, Rosskopf EN, Shelby RA (2002) Field evaluation of plant growth promoting rhizobacteria amended transplant mixes and soil solarization for tomato and pepper production in Florida. Plant Soil 238:257266

Kundu BS, Gaur AC (1980) Effect of nitrogen fixing and phosphate solubilizing microorganisms as single and composite inoculants on cotton. Ind J Mirobiol 20:225-229

Lal S, Tabacchioni S (2009) Ecology and biotechnological potential of Paenibacillus polymyxa: a minireview. Ind J Mirobiol 49:2-10

Lane DJ (1991) 16S/23S rRNA sequencing. In: Stackebrandt E, Goodfellow $M$ (eds) Nucleic acid techniques in bacterial systematics. Wiley, Chichester, pp 115-175

Lanyi B (1987) Classical and rapid identification methods for medically important bacteria. Methods Microbiol 19:1-67

Lowry OH, Rosebrough NJ, Farr AL, Randall RJ (1951) Protein measurement with the Folin-phenol reagent. J Biol Chem 193:265-275

Mahadevan A, Shridhar R (1986) Methods in physiological plant pathology. Sivakami publications, Madras, p 213

Marschner P, Crowley D, Rengel Z (2011) Rhizosphere interaction between microorganisms and plants govern iron and phosphorus acquisition along the root axis-model and research methods. Soil Biol Biochem 43:883-894

Martínez-Viveros O, Jorquera MA, Crowley DE, Gajardo G, Mora ML (2010) Mechanisms and practical considerations involved in plant growth promotion by rhizobacteria. J Soil Sci Plant Nutr 10:293-319

McSpadden Gardener BB (2004) Ecology of Bacillus and Paenibacillus spp. in agricultural systems. Phytopathology 94: $1252-1258$

Morgan JA, Bending GD, White PJ (2005) Biological costs and benefits to plant-microbe interactions in the rhizosphere. J Exp Bot 56:1729-1739

Mullis KB (1990) The unusual origin of the polymerase chain reaction. Sci Am 262(4):56-65

Nicholson W (2002) Roles of Bacillus endospores in the environment. Cell Mol Life Sci 59:410-416

Ona O, Smets I, Gysegom P, Bernaerts K, Van Impre J, Prinsen E, Vanderleyden $\mathrm{J}$ (2003) The effect of $\mathrm{pH}$ on indole-3-acetic acid (IAA) biosynthesis of Azospirillum brasilense Sp7. Symbiosis 35:199-208

Pal SS (1998) Interaction of an acid tolerant strain of phosphate solubilizing bacteria with a few acid tolerant crops. Plant Soil 198:169-177

Raddadi N, Cherif A, Boudabous A, Daffonchio D (2008) Screening of plant growth promoting traits of Bacillus thuringiensis. Ann Microbiol 58:47-52

Richardson AE, Barea JM, McNeill AM, Prigent-Combaret C (2009) Acquisition of phosphorus and nitrogen in the rhizosphere and plant growth promotion by microorganisms. Plant Soil 321:305-339

Rosas SB, Andres JA, Rovera M, Correa NS (2006) Phosphate solubilizing Pseudomonas putida can influence rhizobia-legume symbiosis. Soil Biol Biochem 38:3502-3505

Sahin F, Cakmakci R, Kantar F (2004) Sugar beet and barley yields in relation to inoculation with N2-fixing and phosphate solubilizing bacteria. Plant Soil 265:123-129 
Saitou N, Nei M (1987) The neighbor-joining method: a new method for reconstructing phylogenetic trees. Mol Biol Evol 4:406-425

Sambrook J, Fritschim EF, Maniatis T (1989) Molecular cloning: a laboratory manual. Cold spring Harbor Laboratory Press, New York

Schwyn B, Neilands JB (1987) Universal chemical assay for detection and determination of siderophore. Anal Biochem 160:47-56

Sharma A, Johri BN (2003) Growth promoting influence of siderophore-producing Pseudomonas strains GRP3A and PRS9 in maize (Zea mays L.) under iron limiting conditions. Microbiol Res 158:243-248

Shishido M, Breuil C, Chanway CP (1999) Endophytic colonization of spruce by plant growth promoting rhizobacteria. FEMS Microbiol Ecol 29:191-196

Shoebitz M, Ribaudo CM, Pardo MA, Cantore ML, Ciampi L, Curá JA (2009) Plant growth promoting properties of a strain of Enterobacter ludwigii isolated from Lolium perenne rhizosphere. Soil Biol Biochem 41:1768-1774

Siddiqui ZA (2006) PGPR: prospective biocontrol agents of plant pathogens. In: Siddiqui ZA (ed) PGPR: biocontrol and biocontrol. Springer, Netherlands, pp 112-142

Smibert RM, Krieg NR (1994) Phenotypic characterization. In: Gerhardt P, Murray RGE, Wood WA, Krieg NR (eds) Methods for general and molecular bacteriology. ASM, Washington, DC, pp 607-654

Spaepen S, Vanderleyden J, Remans R (2007) Indole-3-acetic acid in microbial and microorganism-plant signaling. FEMS Microbiol Rev 31:425-448

Spaepen S, Dobbelaere S, Croonenborghs A, Vanderleyden J (2008) Effects of Azospirillum brasilense indole-3-acetic acid production on inoculated wheat plants. Plant Soil 312:15-23

Subbiah BV, Asija GL (1956) A rapid procedure for the estimation of available nitrogen in soils. Curr Sci 25:259-260

Sudha SN, Jayakumar R, Sekar V (1999) Introduction and expression of the cry1Ac gene of Bacillus thuringiensis in a cereal associated bacterium, Bacillus polymyxa. Curr Microbiol 38:163-167
Sundra Rao WVB, Sinha MK (1963) Phosphate dissolving organisms in soil and rhizosphere. Indian J Agric Sci 33:272-278

Swain MR, Naskar SK, Ray RC (2007) Indole-3-acetic acid production and effect on sprouting of Yam (Dioscorea rotundata L.) minisetts by Bacillus subtilis isolated from culturable cowdung microflora. Pol J Microbiol 56:103-110

Thompson JD et al (1997) The CLUSTAL_X windows interface: flexible strategies for multiple sequence alignment aided by quality analysis tools. Nucl Acids Res 25:4876-4882

Timmusk S, Nicander B, Granhall U, Tillberg E (1999) Cytokinin production by Paenibacillus polymyxa. Soil Biol Biochem 31:1847-1852

Trivedi P, Pandey A (2008) Plant growth promotion abilities and formulation of Bacillus megaterium strain B 388 (MTCC6521) isolated from a temperate Himalayan location. Indian J Microbiol 48:342-347

Tsavkelova EA, Klimova SY, Cherdyntseva TA, Netrusov AI (2006) Microbial producers of plant growth stimulators and their practical use: a review. Appl Biochem Micro 42:117-126

Tsavkelova EA, Cherdyntseva TA, Klimova SY, Shestakov AI, Botina SG, Netrusov AI (2007) Orchid-associated bacteria produce indole-3-acetic acid, promote seed germination, and increase their microbial yield in response to exogenous auxin. Arch Microbiol 188:655-664

Whipps JM (2001) Microbial interactions and biocontrol in the rhizosphere. J Exp Bot 52:487-512

Yao AV, Bochow H, Karimov S, boturov U, Sanginboy S, Sharipov K (2006) Effect of FZB24 Bacillus subtilis as a biofertilizer on cotton yields in field tests. Arch Phytopathol Plant Prot 39:1-6

Zaidi A, Khan S (2005) Interactive effect of rhizospheric microorganisms on growth, yield and nutrient uptake of wheat. J Plant Nutr 28:2079-2092

Zaidi A, Khan MS, Ahemad M, Oves M (2009) Plant growth promotion by phosphate solubilizing bacteria. Acta Microbiol Immunol Hung 56:263-284 